\title{
A Comparative Study on Teaching Effects of Different Innovative Methods for Curriculum System: An Students' self-evaluation Study
}

\author{
LUO Lingling, WANG Na \\ Research Center for Philosophy of Science and Technology \\ Northeastern University, \\ Shenyang, China
}

\author{
ZHANG Ping \\ School of Humanities and Law \\ Northeastern University, \\ Shenyang, China,
}

\author{
ZHOU Chunfang \\ Department of Learning and Philosophy, \\ Aalborg University \\ 9000 Aalborg
}

\begin{abstract}
In order to test the feasibility of the curriculum system of TRIZ used in humanities and social science majors, compared with the traditional creativity developing, this study will test whether it is effective to cultivate students' creativity and to train their ability to solve problems. This study designs the randomly experimental targets in the two control groups for pretest and post-test. This study tests creative thinking and student self-evaluation questionnaire, and the result indicates that in terms of the pretest for the two groups of students the indicators have no significant difference. In light of the post-test, for the two groups of students, their creative thinking indicators have improved significantly. However, the differences between the experimental group and the control group are not significant. Finally, this study has discussed the value of TRIZ Course contained in Humanities and Social Science Teaching and addressed the needs to improve.
\end{abstract}

Keywords-TRIZ courses, Creative course, creativity selfevaluation, problem-solving ability

\section{INTRODUCTION}

In recent years, the Chinese government tried to popularize innovative approaches, with efforts to promote TRIZ methods. For the college students, TRIZ methods in business and science and engineering majors, such as mechanical design expertise in promotion get better results. But there are different opinions on whether the students coming from the humanities and social sciences majors carry out related training programs. Whether this course system can be applied to the students in the field of humanities and social sciences? Compared with the teaching system of traditional creativity developing (spreading for nearly thirty years in Chinese colleges and universities), whether TRIZ teaching system has the effective ways in the training of students' creative ability or solving problems?

\section{The THEORETICAL BACKGROUND OF THIS STUDY}

A. The feasibility for TRIZ innovation theory used in nontechnical areas

The earliest works of this field come from the scholars, Boris Zlotin and Alla Zusman, who explore the possibility of TRIZ innovation theory in the social sciences[1]. Boris Zlotin and Alla Zusman proposed that TRIZ should be extended to be applied to non-technical areas, because TRIZ analytical tools and psychological operators can be applied directly or can be easily changed to be applied to non-technical areas; for instance, separation and self-service can be seen as parts of the principle of universal.

Regarding the TRIZ innovation theory applied to specific applied research in non-technical areas, Darrell Mann has led the research team that have made the mostly contributions [2]. Gennady Retseptor presented 40 innovative measures in the field of quality management, and increased customer satisfaction for the 40 innovative measures. Jun Zhang, KahHin Chai, Kay-Chuan Tan and others give 40 principles of areas of service operations and they have been equipped with the cases for a corresponding service operation field[3]. Dana G.Marsh et.al who give the corresponding cases and 40 innovative measures in the field of education. Lou Yonghai, Li Jianhua (2009) demonstrated in the study of how to use the principle of separation of four methods - the time separation, spatial separation, separation conditions, and separation systems-for business model innovation]. Lu Rongsheng, Zhangfeng Bo et al. (2010) address the application of innovative measures and contradictory arguments on China's express delivery company's innovation strategy. Zhang Yaqiang, Sang Xiufeng et al. have discussed how the separation principle can be applied to the management field. They have defined 35 parameters generally from the management areas, and proposed the principle of separation of management field [4]. 


\section{B. Cultivating How to Access the Creativity Teaching and Student Self-Evaluation}

As early as 2004, it was suggested that the difference between creative teaching and teaching creativity should be clear. The former refers to the use of imaginative approaches to make learning more funny and effective, while the latter concerns about the attitudes of creative teaching, and teaches how to develop students' creative thinking and behavior. Despite the creative teaching has its undeniable value and it is believed that it has a lasting impact, education ultimately should focus on creativity training[5] .

According to Csikszentmihalyi's creativity systems theory (1999), the teacher is the gatekeeper of students' creativity and creative product, whose teaching attitudes and academic expectations of students are under the direct control of the creative results. Some studies indicate that seemingly attitudes and support will have a positive impact on students' creativity, but some studies have shown that teachers are almost in an opposite and disapproval attitude towards students' creative behavior. The teacher is more likely to encourage students' creativity and related behavior, but the conservativeauthoritarian teachers favor uncreative behavior. As teachers, they have this paradox. The misleading feedback of teachers' creativity will weaken students' creative self-concept and selfefficacy, and further hindered students' creativity performance [6]. Some studies have found the definitions of creativity given by the teachers which are different by the students and experts. The concept of creative self-discovery is seen as a key factor in discovering innovation performance. Therefore, testing students' creativity and assessing ability is also a key indicator of teaching effectiveness.

\section{STUDY DESIGN}

\section{A. The Purpose of the Experiment}

The purpose of the experiment is to understand the TRIZ innovative methods in humanities and social sciences with the effect differences between the initial training and general creativity developing and thinking courses. It is expected that through experiments, it should help teachers analyze the different training methods with advantages and disadvantages, choosing the most effective and the most appropriate teaching content, summarizing directions and recommendations to improve such teaching.

This study chooses the students' innovative teaching contents and manners in humanities and social science as the target and designs two different types of teaching contents: the experimental group based on teaching TRIZ innovative methods and the control group based on the traditional teaching of creativity. The two groups of students have accepted teaching content, as can be shown in details from Annex. It is compared the different effects of two teaching system for training students' creativity.

\section{B. Assessment Tools}

(1) Five level subjective assessment for teaching effect, namely, the evaluation of self-creativity and problem solving ability is taken before and after the course learning for the students.

(2) Five level of teaching content, namely, after the end of classes, the students will give the evaluations to the list of teaching contents.

\section{Experimental Design Types}

Randomly assigned to subjects of two controlled group measured before and after the experiment

\section{Experimental Hypothesis}

Assumption 1A: According to the view of liberal arts for primary TRIZ training receiver, their evaluation of selfcreativity is significantly greater than that of the one who are not subject to training.

Assumption 1B: According to the view of liberal arts for primary TRIZ training receiver, their ability to solve difficult problems is significantly higher than that of the one who are not subject to training.

Assumption 1C: According to the view of liberal arts for primary TRIZ training receivers, their evaluation of the degree for improving self-creativity is significantly higher than that of the one who has accepted the general creativity developing training.

Assumption 1D: According to the view of liberal arts for primary TRIZ training receiver, their evaluation of the degree for improving the ability of problem-solving is significantly higher than that of the one who has accepted the general creativity developing training.

\section{E. Research Procedures}

(1) Use the self-complied teaching effect evaluation questionnaires to do the experimental pretest for the college students' creative thinking levels in the experimental group and the control group.

(2) For the formal experiment, the control group received 40 hours for learning the general creativity developing courses and the experimental group received 40 hours for TRIZ initial training.

(3) After 10 weeks, at the end of the experiment, selfcomplied teaching effect evaluation questionnaires are used again to do the experimental post-test in the experimental group and the control group.

(4) Statistical data processing.

\section{FINDINGS}

In this experiment, the students in the experimental group are from the Major of Administration Management, Public Utilities Management Business, Ideological and Political Education. The teaching content is about TRIZ (see TABLE I). The students in control group are specializing in Law, Economics and Journalism. The teaching content is about traditional creative thinking and methods (see TABLE I). 
In order not to affect the normal school teaching order, this experiment takes the teaching classes as a unit, and teaching assignment is carried out in accordance with the normal teaching schedule. The experiment has been done from the second semester of the academic year, namely, from 2014 to 2015, through 1 week to 10 weeks ( 10 weeks with 40 hours).
During pairwise comparison, the number of the samples in pretest and post-test has been naturally decreased.

A. The comparison between Students' self-evaluation in the experimental group before and after

TABLE I. THE COMPARISON OF EVALUATION BETWEEN GROUP 1 STUDENTS' SELF-CREATIVITY AND PROBLEM-SOLVING ABILITY BEFORE AND AFTER

\begin{tabular}{|c|c|c|c|c|c|c|c|c|}
\hline \multicolumn{6}{|c|}{ Descriptive Statistics of Paired Sample } & \multicolumn{3}{|c|}{$\begin{array}{l}\text { Comparing the differences of paired } \\
\text { samples }\end{array}$} \\
\hline \multicolumn{2}{|r|}{ Statements } & $\begin{array}{l}\text { Mean } \\
\text { value }\end{array}$ & $\mathbf{N}$ & $\begin{array}{l}\text { Standard } \\
\text { deviation }\end{array}$ & SE Mean & $\mathbf{t}$ & df & (bilateral) \\
\hline \multirow{2}{*}{ Paired 1} & Are you familiar with TRIZ? (Before the course) & 1.36 & 45 & .679 & .101 & -20.322 & 44 & .000 \\
\hline & Are you familiar with TRIZ ? (After the course) & 4.58 & 45 & 1.011 & .151 & & & \\
\hline \multirow{2}{*}{ Paired 2} & $\begin{array}{c}\text { What do you think of your own creativity? (Before the } \\
\text { course) }\end{array}$ & 4.11 & 45 & 1.265 & .189 & -3.129 & 44 & .003 \\
\hline & $\begin{array}{l}\text { What do you think of your own creativity? (After the } \\
\text { course) }\end{array}$ & 4.71 & 45 & .991 & .148 & & & \\
\hline \multirow{2}{*}{ Paired 3} & $\begin{array}{l}\text { What do you think of the ability to solve difficult } \\
\text { problems? (Before the course) }\end{array}$ & 4.64 & 45 & 1.111 & .166 & -1.376 & 44 & .176 \\
\hline & $\begin{array}{l}\text { What do you think of the ability to solve difficult } \\
\text { problems? (After the course) }\end{array}$ & 4.93 & 45 & 1.031 & .154 & & & \\
\hline
\end{tabular}

For Group 1, before and after TRIZ courses, subjective ratings of the related issues to creativity are improved. For Group1, the self-evaluation is paired with samples T-test. The students have got the creative training before and after, they have subjective self-cognition differences in their creativity and problem-solving. The understandings of TRIZ and selfevaluation of creativity have reached significant levels.

\section{B. The comparison between Students' self-evaluation in the} control group before and after

TABLE II. THE COMPARISON OF EVALUATION BETWEEN GROUP 2 STUDENTS' SELF-CREATIVITY AND PROBLEM-SOLVING ABILITY BEFORE AND AFTER

\begin{tabular}{|c|c|c|c|c|c|c|c|}
\hline \multicolumn{9}{|c|}{ Descriptive Statistics of Paired Sample } & \multicolumn{2}{c|}{ Comparing the differences of paired } \\
samples
\end{tabular}

The self-evaluation of Group 2 is paired with samples Ttest. When the students have got the training for creativity before and after, there are subjective self-cognition differences in creativity and problem-solving ability. It can be found in students' cognition is positive, and subjective evaluation of the indicators has improved. Moreover, the differences have reached at a statistically significant level.

\section{Self-evaluation of experimental group and control group after experiment}

As can be seen from the statistical data in TABLE III, there are no significant differences between Levene test of variance equations for the post-test in the experimental group and control group. It indicates that evaluation between the students' self-creativity and problem-solving ability has improved after learning courses. The mean value of the experimental group is slightly higher than the mean value of the control group, but the differences did not reach the statistical significance.

\section{RESULTS}

Experimental Assumption 1A is acceptable, and the Assumption 1B, 1C and 1D are not accepted.

\section{Discussions}

First, for humanities and social science students, the effectiveness of teaching TRIZ method is not clearly superior to that of the traditional teaching of creation. TRIZ method is originated from the inventive methods for solving technical problems as their advantages. For the humanities and social sciences, this method should be given further exploration. The 
development of creativity based on the traditional creativity developing is inclining to the psychological approach, which might be more suited to the students in the field of humanities and social science.

TABLE III. THE COMPARISON OF EVALUATION BETWEEN THE STUDENTS' SELF-CREATIVITY AND PROBLEM-SOLVING ABILITY IN THE EXPERIMENTAL GROUP AND CONTROL GROUP AFTER EXPERIMENT

\begin{tabular}{|c|c|c|c|c|c|c|c|}
\hline \multicolumn{6}{|c|}{ Descriptive statistics } & \multicolumn{2}{|c|}{ Levene test of variance equations } \\
\hline & Grouping & $\mathrm{N}$ & Mean value & $\begin{array}{l}\text { Standard } \\
\text { deviation }\end{array}$ & SE Mean & $\mathrm{F}$ & Sig. \\
\hline \multirow{2}{*}{$\begin{array}{l}\text { 1. After training, what do you think of your } \\
\text { creativity? }\end{array}$} & 1 & 61 & 4.59 & .973 & .125 & 1.596 & .209 \\
\hline & 2 & 72 & 4.44 & .767 & .090 & & \\
\hline \multirow{2}{*}{$\begin{array}{l}\text { 2. After training, what do you think of the } \\
\text { ability to solve difficult problems? }\end{array}$} & 1 & 61 & 4.70 & 1.070 & .137 & 3.791 & .054 \\
\hline & 2 & 72 & 4.64 & .698 & .082 & & \\
\hline \multirow{2}{*}{$\begin{array}{l}\text { 3.After training, what do you think of the } \\
\text { overall capacity to solve problems in the } \\
\text { future? }\end{array}$} & 1 & 61 & 5.00 & .966 & .124 & .032 & .859 \\
\hline & 2 & 72 & 4.89 & .742 & .087 & & \\
\hline
\end{tabular}

Second, TRIZ in the field of humanities and social sciences has not a long history in teaching and needs to strengthen the combination of the case studies of this field with the summary of innovative principles, in order to get better teaching results.

Third, according to the details of teaching content analysis from TRIZ student evaluation, the students give highly evaluation to the following the statements: "main types of contradictions: accept or reject the contradictions and essential contradictions", "40 of innovative measures in eliminating contradictions", "the relationship of the separation principles with 40 of innovative measures", "Multiple criteria decision analysis evaluation"(see TABLE IV). This indicates the core contents of TRIZ and instrumental tools are welcome to students specializing in humanities and social sciences.

TABLE IV. DESCRIPTIVE STATISTICS FOR STUDENT LECTURES EVALUATION

\begin{tabular}{|c|c|c|c|c|c|c|c|}
\hline \multicolumn{4}{|c|}{ Group 1 Innovative approaches to teaching content of TRIZ } & \multicolumn{4}{|c|}{ Group 2 Traditional teaching content of creativity developing } \\
\hline Teaching Content & $\mathrm{N}$ & Mean value & $\begin{array}{l}\text { Standard } \\
\text { deviation }\end{array}$ & Teaching Content & $\mathrm{N}$ & $\begin{array}{l}\text { Mean } \\
\text { value }\end{array}$ & $\begin{array}{l}\text { Standard } \\
\text { deviation }\end{array}$ \\
\hline 1.0 Course Overview & 45 & 3.40 & .780 & $\begin{array}{c}\text { 1.1 Learning objects of creativity } \\
\text { developing }\end{array}$ & 64 & 2.92 & .719 \\
\hline 1.1 Innovation and creative thinking & 45 & 3.87 & .894 & 1.2 The history of creativity developing & 64 & 2.56 & .906 \\
\hline $\begin{array}{c}\text { 1.2System innovation (TRIZ) methods } \\
\text { Overview }\end{array}$ & 45 & 3.71 & 1.014 & $\begin{array}{c}\text { 1.3The significance and methodology } \\
\text { of creativity developing }\end{array}$ & 64 & 3.39 & .919 \\
\hline 2.1 Mindset and the type & 45 & 3.67 & 1.000 & 2.1 Creativity activities'elements & 64 & 3.41 & .706 \\
\hline 2.2 Nine screen methods & 45 & 3.71 & .757 & 2.2 Creation process mode & 64 & 3.62 & .882 \\
\hline 2.3 STIC changing methods & 45 & 3.84 & .824 & 3.1Personality and creative personality & 64 & 4.00 & .713 \\
\hline 2.4 Six Thinking Hats & 45 & 3.91 & 1.221 & $\begin{array}{l}3.2 \text { Promoting ideal personality of } \\
\text { creation }\end{array}$ & 64 & 4.17 & .846 \\
\hline 2.5Idealized Methods & 45 & 3.64 & .773 & 4.1 Creativity Overview & 64 & 2.73 & .840 \\
\hline 3.1 Problem discovery tools & 45 & 3.67 & .826 & $\begin{array}{l}4.2 \text { Creativity and development } \\
\text { pathways and basis }\end{array}$ & 64 & 4.06 & .833 \\
\hline 3.2 Causal analysis & 45 & 3.80 & 1.100 & 4.3 Obstacles of Developing Creativity & 64 & 4.16 & .718 \\
\hline 3.3 Functional Analysis & 45 & 3.91 & .701 & 5.1Overview of Creative Thinking & 64 & 3.48 & .873 \\
\hline 4.1 Outline & 45 & 3.07 & 1.009 & 5.2 Forms of creative thinking & 64 & 3.91 & .868 \\
\hline 4.2 Problems' type & 45 & 3.56 & .813 & 6.1Creative observation Overview & 64 & 3.61 & .866 \\
\hline 4.3 The methods of selection order & 45 & 3.67 & .977 & 6.2 Creative observation skills & 64 & 4.27 & .761 \\
\hline $\begin{array}{l}\text { 5.1 Main types of contradictions :accept or } \\
\text { reject the contradictions and essential } \\
\text { contradictions }\end{array}$ & 45 & 4.04 & .796 & 7.1Overview of techniques to creation & 64 & 3.73 & .963 \\
\hline $\begin{array}{l}5.240 \text { of innovative measures in eliminating } \\
\text { contradictions }\end{array}$ & 45 & 4.02 & .892 & 7.2Free-thinking techniques of creation & 64 & 4.37 & .724 \\
\hline $\begin{array}{l}\text { 5.3 System parameters and Contradiction } \\
\text { Matrix }\end{array}$ & 45 & 3.80 & .842 & & & & \\
\hline 6.1 Essential contradictions overview & 45 & 3.62 & .834 & & & & \\
\hline $\begin{array}{l}\text { 6.2 The separation principles of essential } \\
\text { contradictions }\end{array}$ & 45 & 3.80 & .894 & & & & \\
\hline $\begin{array}{l}\text { 6.3 The relationship of separation principles } \\
\text { with } 40 \text { of innovative measures }\end{array}$ & 45 & 4.13 & .815 & & & & \\
\hline $\begin{array}{c}\text { 6.4 Comprehensive application of the } \\
\text { principle of separation }\end{array}$ & 45 & 3.96 & .903 & & & & \\
\hline 7.1 S curve and system evolution & 45 & 3.47 & .944 & & & & \\
\hline $7.2 \mathrm{~S}$ curve at the System - subsystems level & 45 & 3.71 & .695 & & & & \\
\hline $7.3 \mathrm{~S}$ curve at the System - functional level & 45 & 3.67 & .853 & & & & \\
\hline
\end{tabular}




\section{REFERENCES}

[1] Boris Zlotin and Alla Zusman Evaluation of Organizations and Social Systems [J].Journal of TRIZ 1993.1:pp.73-81.

[2] Retseptor G.Inventive Principles in Customer Satisfaction Enhancement[J].The TRIZ Journal,2007,pp.1-40.

[3] Zhang J,Chai K H,Tan K C.40 inventive principles with applications in service operations management[J].The TRIZ Journal,2003:pp. 1-16.
[4] Zhang Y,Sang X.Application of separation principle in Management innovation based on TRIZ[C]//Computer Science and Service System (CSSS) ,2011International Conference on.IEEE,2011: pp. 2116-2119.

[5] Magdalena G. Grohman,Krzysztof J. Szmidt.Teaching for Creativity: How to Shape Creative Attitudes in Teachers and in Students, in Mary Banks Gregerson,James C. Kaufman,Heather T. Snyder(ed),Teaching Creatively and Teaching Creativity, Springer New York,2013: pp. 15-35.

[6] Aik.Kwang.Ng, Ian.Smith. The paradox of promoting creativity in the Asian classroom: an empirical investigation.Genetic, Social, and General Psychology Monographs,130 (4) (2004), pp. 307-330. 